\title{
EFFECT OF MOISTURE ABSORPTION ON MECHANICAL PROPERTIES OF JUTE-SISAL REINFORCED EPOXY COMPOSITE - AN EXPERIMENTAL INVESTIGATION
}

\author{
D.Tamilvendan ${ }^{1}$, N.Banupriya ${ }^{2}$, K.Anagha Udayakumar ${ }^{3}$, M.Guruprashant ${ }^{4}$, K.Srisharadevi ${ }^{5}$ \\ ${ }^{1}$ Assistant Professor - Aeronautical Engineering, Hindusthan College of Engineering and Technology, \\ Coimbatore, Tamilnadu, India. \\ ${ }^{2-5}$ UG - Aeronautical Engineering, Hindusthan College Of Engineering and Technology, \\ Coimbatore, Tamilnadu, India.
}

\begin{abstract}
In the context of sustainable development, considerable interest is being shown in the use of natural fibres as reinforcement in polymer composites and in the development of resins from renewable resources. Natural fibres are widely used for reinforcement in polymer composites. The advantages of natural fibres such as renewable, environmentally friendly, low cost, and many more are well known. Natural fibres are used in many applications such as the aerospace industry, marine sector, automotive industry, sporting segments, and construction industries. This paper focuses on how the presence of water plays a crucial role in the mechanical behavior of natural fibres. Water plays the role of plasticizer. In practice, the major drawbacks of using natural fibre are their high degree of moisture absorption and poor dimensional stability. In this paper, 8 layers and 6 layers of jute and sisal fibre were selected as the reinforcing materials and epoxy resin was chosen as the matrix. The compression molding process was adopted to produce the hybrid composite. Moisture absorption tests were conducted by immersing composite specimens in environmental conditions such as distilled water at room temperature for different time periods like $24 \mathrm{hrs}, 48 \mathrm{hrs}$, and $72 \mathrm{hrs}$. The moisture absorption and mechanical properties such as tensile strength, the flexural strength of these composites have been evaluated as per ASTM standards. The process of water absorption of these composites was found to approach Fickian diffusion behaviour. Maximum water uptake values were evaluated; the results revealed that the effect of water absorption showed a significant reduction in the mechanical performance of all composites.
\end{abstract}

Keywords: Natural fibres, Jute-Sisal-Epoxy Composites, Moisture absorption, Tensile Test, Flexural Test, Impact Test, ILSS Test.

\section{INTRODUCTION}

The environmental consciousness as well as the government legislation around the world has encouraged the academic and industrial research to develop eco-friendly, sustainable and biodegradable composite materials, thus often referred to as "green composites" [1]. Natural fibres are those that aren't synthetic or man-made, to put it simply. They can be sourced from plants and animals. The utilization of natural fibres from both renewable and non-renewable resources such as oil palm, sisal, flax, and jute to make composite material has gotten a lot of attention in recent decades [2]. The interest in natural plant fibres (flax, hemp, jute, kenaf, etc.) [3-6] as reinforcement in polymer matrix has grown quickly in the last decade. Several advantages in comparison with synthetic fibres can explain it. They have low density, are annually renewable, and therefore are low in cost. Natural fibres are biodegradable, are crucial at the end of life of products, and have comparable specific strength and modulus as traditional glass fibres. Industries as automotive [7, 8] and construction [9] have started the manufacturing of products using natural fibre, to improve the environmental impact of the product due to the inexpensive price of natural reinforcements. There are also some drawbacks in the use of natural fibre reinforced composites. Hydrophilic natural fibres are incompatible with hydrophobic thermosetting resins, and it is necessary to improve the adhesion between fibre and matrix, the use of chemical treatments $[10,11]$. Natural fibres as reinforcement have been limited by their susceptibility to water absorption, due to their chemical composition being rich in cellulose, hydrophilic in nature. Water absorption results in the swelling of the fibre that could reduce the mechanical and dimensional properties of the composites [12-14] as a result of the appearance of micro cracks at fibre-matrix space. There are three major mechanisms [12, 15-17] of water absorption in fibre reinforced polymer composites: diffusion, capillary, and transport of water molecules, respectively. Diffusion mechanism occurs inside the micro gaps between the chains of polymers. Capillary transport mechanism occurs in the gaps at fibre-matrix interface space, if during 


\section{DOI: 10.17148/IARJSET.2021.81245}

manufacturing process the impregnation of the reinforcement with the matrix has been incomplete. In natural fibre composites, the transport of water molecules through the micro cracks that can appear in the matrix is especially important, as a result of the fibre swelling. According to these mechanisms, there are three cases of diffusion behaviour $[18,19]$ known as Fickian diffusion model, anomalous or non-Fickian, and an intermediate case between Fickian and non-Fickian. Natural fibre polymer composites are a composite material consisting of a polymer matrix embedded with high-strength natural fibres like jute, oil palm, sisal, kenaf and flax. Usually, polymers can be categorized into two categories, thermoplastics, and thermosets [20]. The structure of thermoplastic matrix materials consists of one or two dimensional molecular, so these polymers have a tendency to make softer at a raised heat range and roll back their properties throughout cooling. On the other hand, thermosets polymer can be defined as highly cross-linked polymers which cured using only heat, or using heat and pressure, and/or light irradiation. This structure gives to thermoset polymer good properties such as high flexibility for tailoring desired ultimate properties, great strength, and modulus.

\section{MATERIALS AND METHODS}

\section{Material Procurement}

The natural fibres have been purchased from GO GREEN PRODUCTS Pvt Ltd (Pallav Kamala Apartment, No 225 E, First Floor, Gandhi Road, Chennai, and Tamil Nadu 600034). The fibre purchased was delivered in knitted form, and only in case of jute the material was pure, and the rest of the material showed up with hybrid composition. Jute fiber was pure. in case of sisal fiber with a composition of SISAL-60\% and JUTE-40\%. It was purchased in quantity of 1 meter each. The material is been cut in the dimension of $250 \mathrm{~mm} * 250 \mathrm{~mm}$ for the manufacturing of the plate specimen.

For the convenience of mechanical testing, it was procured in the knitted or weaved type since this exhibits better distribution of properties all over the manufactured plate. The fiber angle is $0^{\circ}$ to $90^{\circ}$.
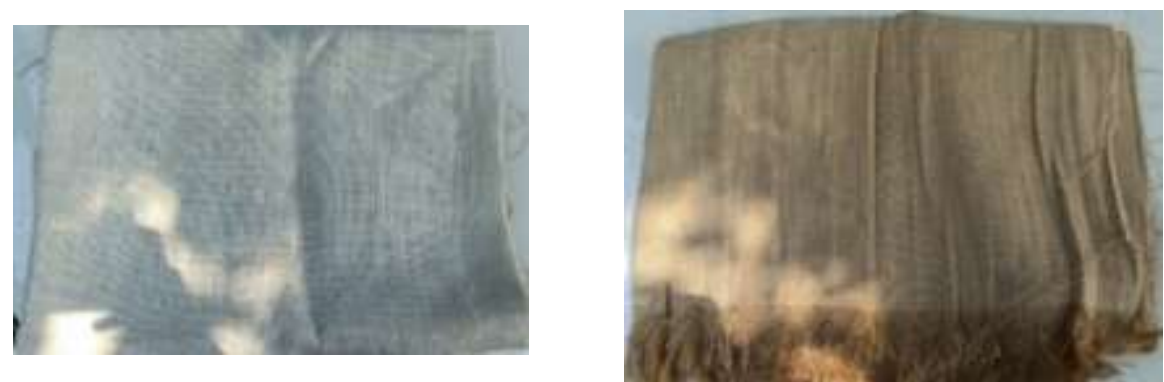

\section{Manufacturing Process}

The manufacturing process was carried out in LMP R\&D laboratory 10/6, 5000 SURESH COMPLEX, NEAR JEEVA SHED, PALLIPALAYAM-638006, ERODE.

EMAIL: lpmranddlab@gmail.com

Compression molding technique was chosen for the manufacturing of composites as the method is comparatively economical and efficient.

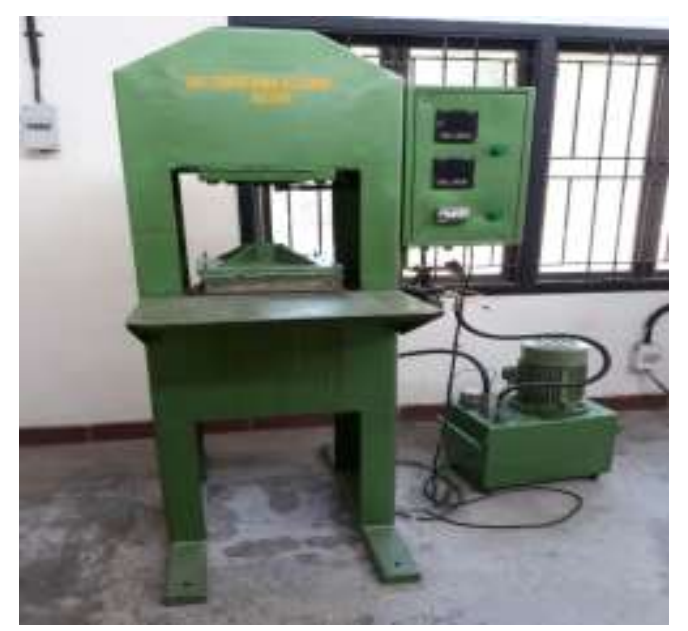

Compression Molding Machine 
Vol. 8, Issue 12, December 2021

DOI: $10.17148 /$ IARJSET.2021.81245

Table 1 Crucial Parameters

\begin{tabular}{|l|l|}
\hline Power & $12 \mathrm{kw}-24 \mathrm{kw}$ \\
\hline Voltage & $220 \mathrm{~V}$ \\
\hline Frequency & $50-60 \mathrm{~Hz}$ \\
\hline Rated Loading Capacity & $350 \mathrm{~kg}$ \\
\hline Plate Thickness & $3 \mathrm{~mm}$ \\
\hline Plate Dimensions & $275^{*} 275 \mathrm{~mm}$ \\
\hline Pressure & $1500 \mathrm{psi}$ \\
\hline Temperature & $85-98^{\circ} \mathrm{C}$ \\
\hline
\end{tabular}

Plates are cut with ASTM standard dimensions for each variation of specimen corresponding to the subjected tests.

- $\quad$ Tensile Test- ASTM D-3039, Universal testing machine, 250x25x3 mm

- $\quad$ Flexural- ASTM D-790, Universal testing machine, 125x13×3 mm

- $\quad$ Impact Test- ASTM D-256, Izod Impact testing machine, 65x13×3 mm

- $\quad$ ILSS Test - ASTM D-2344, Universal testing machine, 6x20x3 mm

\section{Water Absorption}

The test specimens were immersed in distilled water to study the water absorption behavior of natural fibre reinforced composites. The water absorption of natural fibres depends on the exposure time hence the specimens were immersed for different time durations i.e. $24 \mathrm{hrs}, 48 \mathrm{hrs}$, and $72 \mathrm{hrs}$ at room temperature. Moisture absorption studies were performed following the ASTM D 570-98: Standard Test Method for Moisture Absorption of composite. The weight of the samples was measured before subjecting them to distilled water at room temperature. After exposure for 24 hrs, the specimens were taken out from the moist environment and all surface moisture was removed with a clean dry cloth or tissue paper. The specimens were reweighed. The specimens were weighed regularly at $48 \mathrm{hrs}$ and $72 \mathrm{hrs}$ exposure. The moisture absorption was calculated by the weight difference. The percentage weight gain of the samples was measured at different time intervals by using the following equation:

$\% \mathrm{~W}_{\mathrm{m}}=\left(\left(\mathrm{W}_{\mathrm{t}}-\mathrm{W}_{0}\right) \times 100\right) / \mathrm{W}_{0}$

Where $\mathrm{Wt}$ is the weight of specimen at a given immersion time and $\mathrm{W}_{0}$ is the-dry specimen weight.

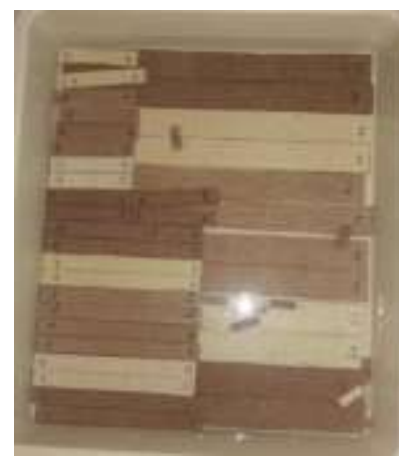

Specimen Immersed for $24 \mathrm{hrs}$

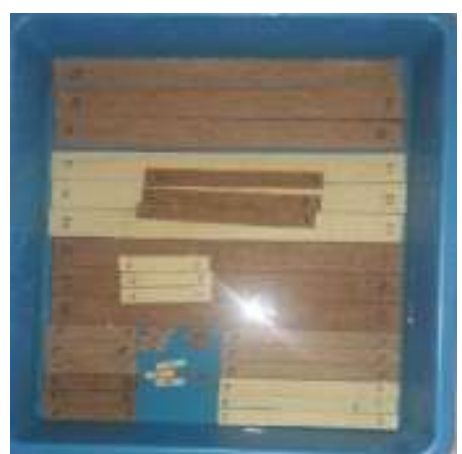

Specimen Immersed for $48 \mathrm{hrs}$

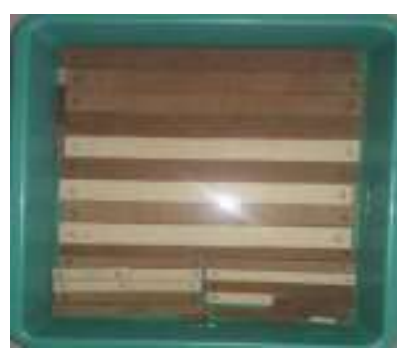

Specimen Immersed for $72 \mathrm{hrs}$

RESULTS AND DISCUSSION

\section{Tests Carried Out}

- $\quad$ Tensile Test- ASTM D-3039, Universal testing machine, 250x25x3 mm

- $\quad$ Flexural- ASTM D-790, Universal testing machine, 125x13×3 mm

- Impact test- ASTM D-256, Izod Impact testing machine, 65x13x3 mm

- Inter-Laminar Shear Strength- ASTM D-2344, Universal testing machine, 6x20x3 mm 
Vol. 8, Issue 12, December 2021

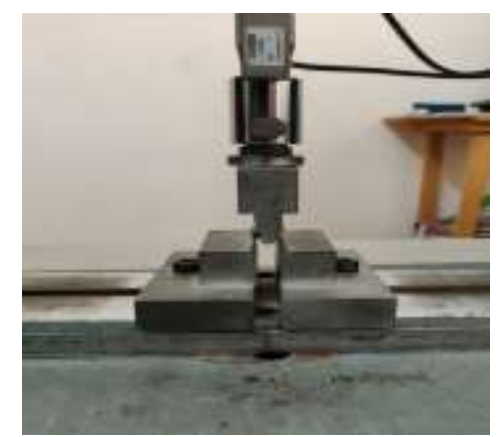

Figure 1 Inter-Laminar Shear Strength Test

DOI: 10.17148/IARJSET.2021.81245

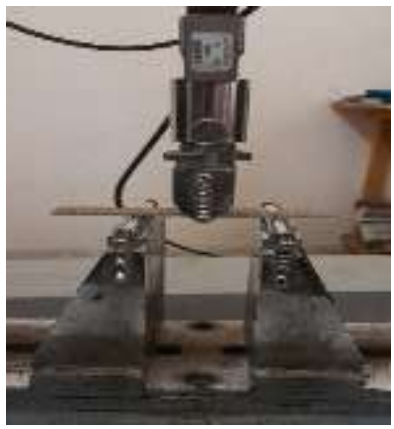

Figure 8 Flexural Test

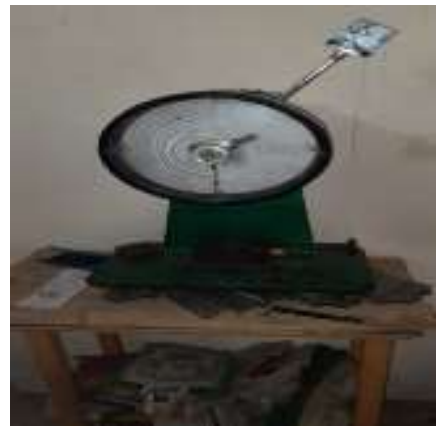

Figure 9 Impact Test

\section{Water Absorption Behavior}

\begin{tabular}{|l|l|l|l|l|l|}
\hline Specimen & No of Layers & Dry specimen & $\mathbf{2 4}$ hrs exposure & $\mathbf{4 8}$ hrs exposure & $\mathbf{7 2}$ hrs exposure \\
\hline \multirow{2}{*}{$\begin{array}{l}\text { Tensile } \\
\text { Specimen }\end{array}$} & 6 & 21 & 23.8 & 25.7 & 27.05 \\
\cline { 2 - 6 } $\begin{array}{l}\text { Flexural } \\
\text { Specimen }\end{array}$ & 6 & 25 & 27.4 & 29.5 & 31.5 \\
\cline { 2 - 6 } Impact & 8 & 3 & 3.5 & 4.2 & 5 \\
\hline Specimen & 6 & 3.8 & 4 & 5.4 & 8 \\
\cline { 2 - 6 } ILSS Specimen & 8 & 3.2 & 3.5 & 4.8 & 6 \\
\cline { 2 - 6 } & 6 & 3.4 & 4.5 & 6.5 & 8.2 \\
\cline { 2 - 6 } & 8 & 0.2 & 0.39 & 0.88 & 0.98 \\
\hline
\end{tabular}

\section{INCREASE IN WEIGHT VS} EXPOSURE TIME
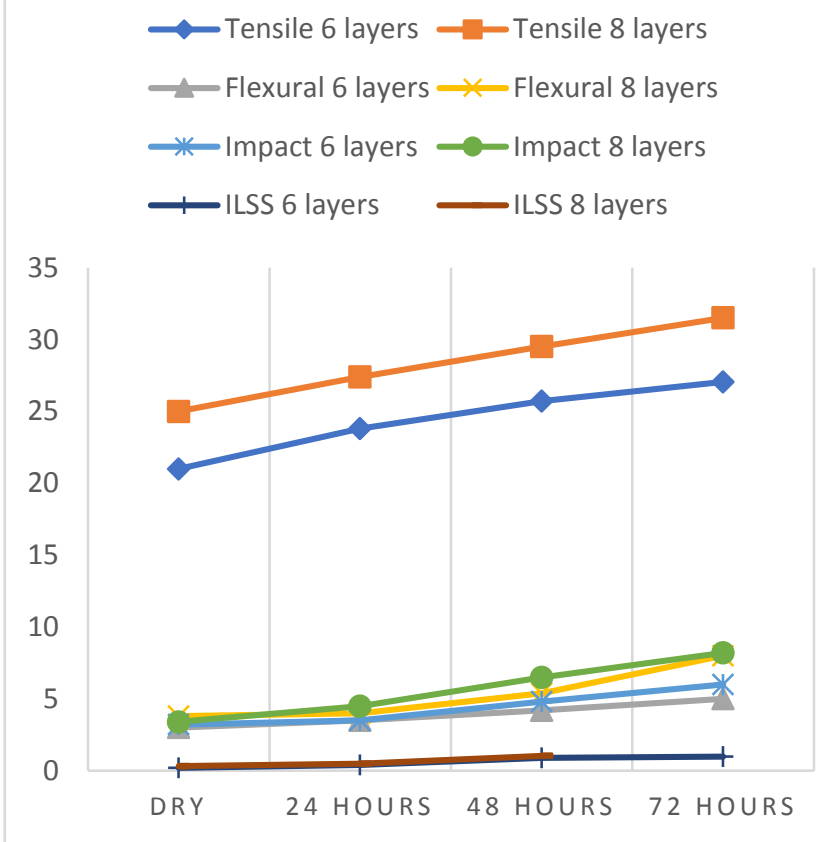

Graph 1: Weight gained after exposure to moisture

Exposure to moisture results in absorption of water into the voids present in the structure. The observation also notes that increase in exposure time to moisture results in increase in the weight of water absorbed. This is evident in the Tensile specimen where the weight of the specimen increased from $21 \mathrm{~g}$ (6 layers) and $25 \mathrm{~g}$ ( 8 layers) to $27.05 \mathrm{~g}$ (6 layers) and $31.5 \mathrm{~g}$ (8 layers) respectively. Other specimens have also shown considerable increase in specimen weight due to moisture 
International Advanced Research Journal in Science, Engineering and Technology

Vol. 8, Issue 12, December 2021

DOI: $10.17148 / I A R J S E T .2021 .81245$

absorption. At the end of 72 hours, water accounts for almost $48 \%$ of the total weight of the specimens.

Effect of Water Absorption on Tensile Strength

\begin{tabular}{|l|l|l|l|l|l|}
\hline $\begin{array}{l}\text { Numbers of } \\
\text { Layers }\end{array}$ & $\begin{array}{l}\text { Exposure } \\
\text { to } \\
\text { Moisture }\end{array}$ & CS Area $\left(\mathbf{m m}^{\mathbf{2}}\right)$ & Peak Load (N) & \% Elongation & UTS $\left(\mathbf{N} / \mathbf{m m}^{\mathbf{2}}\right)$ \\
\hline \multirow{3}{*}{$\mathbf{8}$ Layers } & $\mathbf{2 4} \mathbf{~ h r s}$ & 75 & 8228.599 & 3.750 & 109.715 \\
\cline { 2 - 6 } & $\mathbf{4 8} \mathbf{~ h r s}$ & 75 & 7897.295 & 5.010 & 105.301 \\
\cline { 2 - 6 } & $\mathbf{7 2} \mathbf{~ h r s}$ & 75 & 6224.337 & 7.400 & 82.993 \\
\hline \multirow{3}{*}{ 6 Layers } & $\mathbf{2 4} \mathbf{~ h r s}$ & 75 & 4480.816 & 2.440 & 59.743 \\
\cline { 2 - 6 } & $\mathbf{4 8} \mathbf{~ h r s}$ & 75 & 3997.673 & 2.620 & 53.298 \\
\cline { 2 - 6 } & $\mathbf{7 2} \mathbf{~ h r s}$ & 75 & 3685.087 & 2.630 & 49.138 \\
\hline
\end{tabular}

\section{TENSILE TEST}

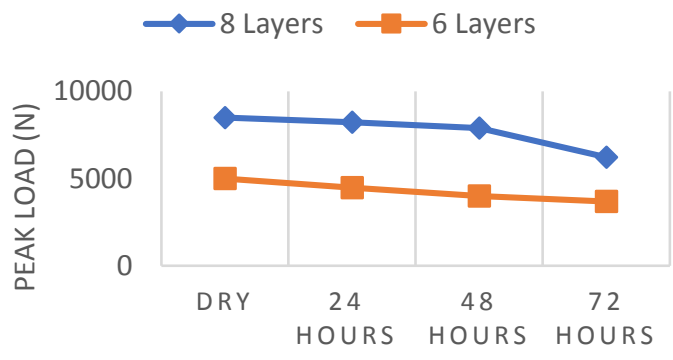

DURATION OF EXPOSURE TO MOISTURE

Graph 2: Tensile Test

Performance of Tensile Test proved that with the increase in water absorption there is a reduction in Tensile Strength. With the increase in moisture absorption, we could see an increase in elongation, which was more evident in the 8-layer composite. 8-layer dry specimen can withstand a peak load of $8500 \mathrm{~N}$ which drops to $6224.337 \mathrm{~N}$ when immersed in water for 72 hours. Similarly for 6-layer specimen can take a peak load of 5000N when dry but it drops to $3685.087 \mathrm{~N}$ after immersing in water for 72 hours. With this, we conclude that there is a significant drop in Tensile properties when exposed to moisture for a prolonged duration.

\section{Effect of Water Absorption on Flexural Strength}

\begin{tabular}{|l|l|l|l|l|l|}
\hline $\begin{array}{l}\text { Number of } \\
\text { Layers }\end{array}$ & $\begin{array}{l}\text { Exposure } \\
\text { to } \\
\text { Moisture }\end{array}$ & CS Area $\left(\mathbf{m m}^{\mathbf{2}}\right)$ & Peak Load (N) & $\begin{array}{l}\text { Flexural } \\
\text { Strength (MPa) }\end{array}$ & $\begin{array}{l}\text { Flexural } \\
\text { Modulus (GPa) }\end{array}$ \\
\hline \multirow{3}{*}{$\mathbf{8}$ Layers } & $\mathbf{2 4} \mathbf{~ h r s}$ & 39 & 220.303 & 141.220 & 7385.773 \\
\cline { 2 - 6 } & $\mathbf{4 8} \mathbf{~ h r s}$ & 39 & 186.537 & 119.575 & 6398.593 \\
\cline { 2 - 6 } & $\mathbf{7 2} \mathbf{~ h r s}$ & 39 & 176.717 & 113.280 & 6281.606 \\
\hline \multirow{3}{*}{$\mathbf{6}$ Layers } & $\mathbf{2 4} \mathbf{~ h r s}$ & 39 & 110.304 & 70.707 & 4198.273 \\
\cline { 2 - 6 } & $\mathbf{4 8} \mathbf{~ h r s}$ & 39 & 107.655 & 69.010 & 3976.051 \\
\cline { 2 - 6 } & $\mathbf{7 2} \mathbf{~ h r s}$ & 39 & 96.256 & 61.703 & 3902.867 \\
\hline
\end{tabular}


Vol. 8, Issue 12, December 2021

DOI: $10.17148 /$ IARJSET.2021.81245

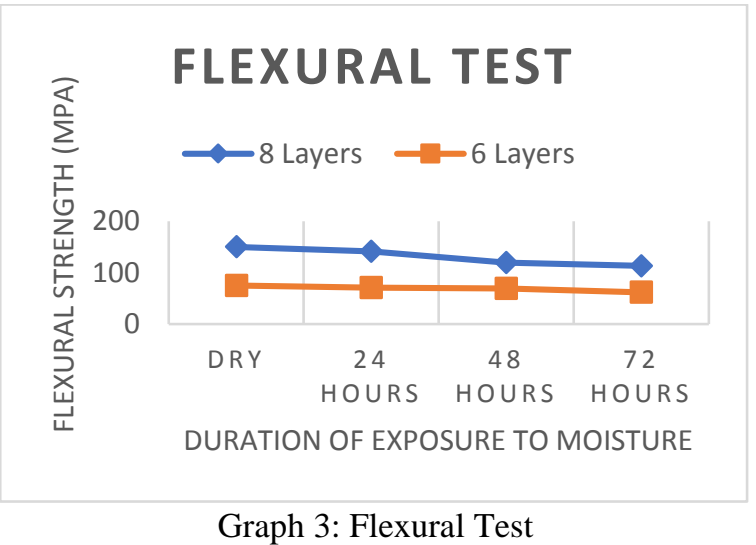

Performance of Flexural Test proved that with the increase in water absorption there is a reduction in Flexural Strength. Flexural strength for 8-layer dry specimen was calculated to be $150 \mathrm{MPa}$ which dropped to $113.280 \mathrm{MPa}$ for a specimen immersed in water for 72 hours. Similar test was conducted for the 6-layer sample which showed a drop from $75 \mathrm{MPa}$ for dry specimen to $61.703 \mathrm{MPa}$ for specimen immersed in water for 72 hours. With this, we conclude that there is a significant drop in Flexural properties when exposed to moisture for a prolonged duration.

Effect of Water Absorption on Impact Strength

\begin{tabular}{|l|l|l|}
\hline $\begin{array}{l}\text { Number of } \\
\text { Layers }\end{array}$ & $\begin{array}{l}\text { Exposure } \\
\text { to } \\
\text { Moisture }\end{array}$ & Izod Impact value in J for 3mm thickness \\
\hline \multirow{3}{*}{ 8 Layers } & $\mathbf{2 4} \mathrm{hrs}$ & 0.90 \\
\cline { 2 - 3 } & $\mathbf{4 8} \mathrm{hrs}$ & 0.70 \\
\cline { 2 - 3 } & $\mathbf{7 2} \mathrm{hrs}$ & 0.65 \\
\hline \multirow{3}{*}{6 Layers } & $\mathbf{2 4} \mathrm{hrs}$ & 0.40 \\
\cline { 2 - 3 } & $\mathbf{4 8} \mathrm{hrs}$ & 0.35 \\
\cline { 2 - 3 } & $\mathbf{7 2} \mathbf{~ h r s}$ & 0.30 \\
\hline
\end{tabular}

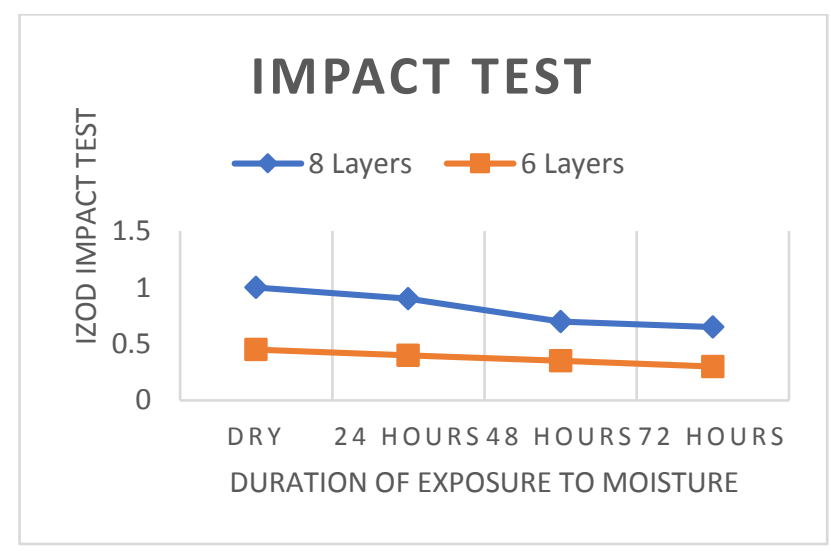

Graph 4: Izod Impact Test

Performance of Impact Test proved that with the increase in water absorption there is a reduction in Toughness of the composite. Impact strength for 8-layer dry specimen was calculated to be $0.95 \mathrm{~J}$ which dropped to $0.65 \mathrm{~J}$ for a specimen immersed in water for 72 hours. Similar test was conducted for the 6-layer sample which showed a drop from $0.45 \mathrm{~J}$ for dry specimen to $0.30 \mathrm{~J}$ for specimen immersed in water for 72 hours. With this, we conclude that there is a significant drop in Impact Strength when exposed to moisture for a prolonged duration. 
DOI: 10.17148/IARJSET.2021.81245

Effect of Water Absorption on ILSS

\begin{tabular}{|c|c|c|c|c|}
\hline $\begin{array}{l}\text { Number of } \\
\text { Layers }\end{array}$ & $\begin{array}{l}\text { Exposure } \\
\text { to } \\
\text { Moisture }\end{array}$ & CS Area $\left(\mathrm{mm}^{2}\right)$ & Peak Load (N) & $\begin{array}{l}\text { Shear Strength } \\
(\mathrm{MPa})=\mathbf{3 P} / \mathbf{4 b h}\end{array}$ \\
\hline \multirow{3}{*}{8 Layers } & 24 hrs & 18 & 559.092 & 23.295 \\
\hline & 48 hrs & 18 & 477.080 & 19.878 \\
\hline & 72 hrs & 18 & 458.647 & 19.110 \\
\hline \multirow{3}{*}{6 Layers } & 24 hrs & 18 & 266.881 & 11.120 \\
\hline & 48 hrs & 18 & 251.165 & 10.465 \\
\hline & 72 hrs & 18 & 223.423 & 9.309 \\
\hline
\end{tabular}

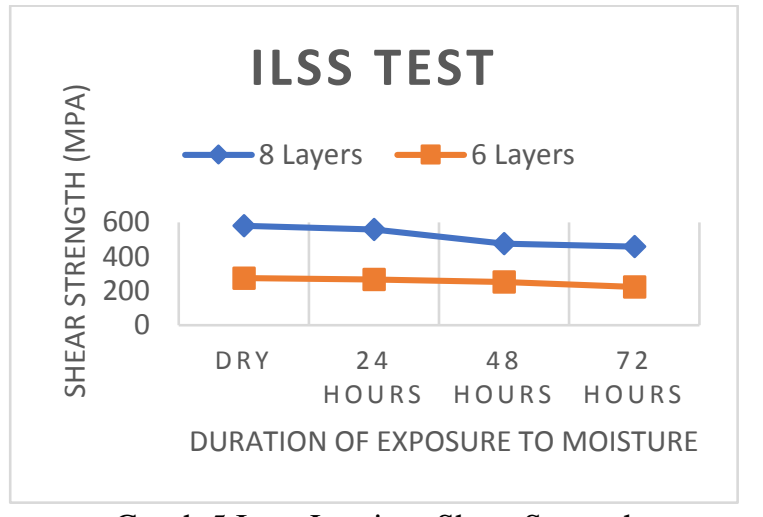

Graph 5 Inter Laminar Shear Strength

Comparing the results from other tests and ILSS test we can conclude that there is comparatively slower reduction in Shear strength properties in the specimens examined. The peak load observed by the 6-layered specimen in dry condition was $580 \mathrm{~N}$ which dropped to $458.647 \mathrm{~N}$ when exposed to water for 72 hours. Similarly for the 8-layered specimen the dry specimen experienced a peak load of $275 \mathrm{~N}$ which dropped to $223.423 \mathrm{~N}$ after being exposed to water for 72 hours. With this observation we conclude that exposure to moisture results in decrease in Shear Strength for Jute-Sisal Fiber composites.

\section{CONCLUSION}

1. It is observed that increase in fiber content results in increase in mechanical properties.

2. With increase in fiber content in the composite it is seen that there is increase in water absorption for same amount of exposure to moisture. On an average the 8-layer specimen absorb 3-4\% more moisture than 6-layer.

3. The water absorption pattern of the composite was found to follow Fickian behavior at room temperature.

4. Due to water absorption the 8-layer Jute-Sisal hybrid composite has a $26.77 \%$ reduction in Tensile Strength and the 6-layer Jute-Sisal hybrid composite has a $26.29 \%$ reduction in Tensile Strength.

5. Due to water absorption the 8-layer Jute-Sisal hybrid composite has a $24.48 \%$ reduction in Flexural Strength and the 6-layer Jute-Sisal hybrid composite has a $17.72 \%$ reduction in Flexural Strength.

6. Due to water absorption the 8-layer Jute-Sisal hybrid composite has a $31.5 \%$ reduction in Impact Strength and the 6-layer Jute-Sisal hybrid composite has a 33.33\% reduction in Impact Strength.

7. Due to water absorption the 8-layer Jute-Sisal hybrid composite has a $20.92 \%$ reduction in ILSS and the 6-layer Jute-Sisal hybrid composite has a $18.75 \%$ reduction in ILSS.

\section{Conflict of Interests}

The authors declare that there is no conflict of Interests regarding the publication of this paper.

\section{REFERENCES}

[1] C. Baillie, Ed., Green Composites. Polymer Composites and Environment, Woodhead Publishing Limited, Cambridge, UK, 2004.

[2]Natural Fibres as sustainable and Renewable Resource for department of eco-friendly composites: A comprehensive Review.

[3] D. N. Saheb and J. P. Jog, "Natural fiber polymer composites: a review," Advances in Polymer Technology, vol. 18, no. 4, pp. 351-363, 1999.

[4] P. Wambua, J. Ivens, and I. Verpoest, "Natural fibres: can they replace glass in fibre reinforced plastics?" Composites Science and Technology, vol. 63 , no. 9 , pp. 1259-1264, 2003. 


\section{International Advanced Research Journal in Science, Engineering and Technology}

\section{Vol. 8, Issue 12, December 2021}

\section{DOI: $10.17148 /$ IARJSET.2021.81245}

[5] J. Summerscales, N. P. J. Dissanayake, A. S. Virk, and W. Hall, "A review of bast fibres and their composites. Part 1. Fibres as reinforcements," Composites Part A: Applied Science and Manufacturing, vol. 41, no. 10, pp. 1329-1335, 2010.

[6] J. Summerscales, N. Dissanayake, A. Virk, and W. Hall, "A review of bast fibres and their composites. Part 2-composites," Composites Part A: Applied Science and Manufacturing, vol. 41, no. 10, pp. 1336-1344, 2010.

[7] M. Karus and M. Kaup, "Natural fibres in the European automotive industry," Journal of Industrial Hemp, vol. 7, no. 1, pp. 119-131, 2002.

[8] D. Puglia, J. Biagiotti, and J. M. Kenny, "A review on natural fibre-based composites_part II: application of natural reinforcements in composite materials for automotive industry," Journal of Natural Fibers, vol. 1, no. 3, pp. 23-65, 2004.

[9] N. Uddin and R. R. Kalyankar, "Manufacturing and structural feasibility of natural fiber reinforced polymeric structural insulated panels for panelized construction," International Journal of Polymer Science, vol. 2011, Article ID 963549, 7 pages, 2011.

[10] Y. Xie, C. A. S. Hill, Z. Xiao, H. Militz, and C. Mai, "Silane coupling agents used for natural fiber/polymer composites: a review," Composites Part A: Applied Science and Manufacturing, vol. 41, no. 7, pp. 806-819, 2010.

[11] M. M. Kabir, H. Wang, K. T. Lau, and F. Cardona, "Chemical treatments on plant-based natural fibre reinforced polymer composites: an overview," Composites Part B: Engineering, vol. 43, no. 7, pp. 2883-2892, 2012.

[12] H. N. Dhakal, Z. Y. Zhang, and M. O. W. Richardson, "Effect of water absorption on the mechanical properties of hemp fibre reinforced unsaturated polyester composites," Composites Science and Technology, vol. 67, no. 7-8, pp. 1674-1683, 2007.

[13] H. Alamri and I. M. Low, "Mechanical properties and water absorption behaviour of recycled cellulose fibre reinforced epoxy composites," Polymer Testing, vol. 31, no. 5, pp. 620-628, 2012.

[14] E. Osman, A. Vakhguelt, I. Sbarski, and S. Mutasher, "Water absorption behavior and its effect on the mechanical properties of kenaf natural fiber unsaturated polyester composites," in Proceedings of the 18th International Conference on Composites Materials (ICCM '11), August 2011.

[15] A. C. Karmaker, "Effect of water absorption on dimensional stability and impact energy of jute fibre reinforced polypropylene," Journal of Materials Science Letters, vol. 16, no. 6, pp. 462-464, 1997.

[16] A. Espert, F. Vilaplana, and S. Karlsson, "Comparison of water absorption in natural cellulosic fibres from wood and one-year crops in polypropylene composites and its influence on their mechanical properties," Composites Part A: Applied Science and Manufacturing, vol. 35, no. 11, pp. 1267-1276, 2004. [17] D Tamilvendan "Mechanical Performance of Jute \& Sisal reinforced Epoxy Composites" International Journal of Advances in Engineering and Management (IJAEM) Volume 3, Issue 12, pp: 575-580, 2021.

[18] T. A. Collings, "Moisture absorption-Fickian diffusion kinetics and moisture profiles," in Handbook of Polymer Fibre Composites, F. R. Jones, Ed., pp. 366-371, Longman Scientific and Technical, Essex, UK, 1994.

[19] C.-H. Shen and G. S. Springer, "Moisture absorption and desorption of composite materials," Journal of Composite Materials, vol. 10, no. 1, pp. 2-20, 1976.

[20] D Tamilvendan, G Mari Prabu, S Sivaraman, A. R. Ravikumar "Mechanical Behaviour of Hybrid Composites Prepared using Sisal-PineappleKenaf Fibre" International Journal of Recent Technology and Engineering (IJRTE)

ISSN: 2277-3878, Volume-8 Issue-5, 202sss

[21] S. H. Ahmad, N. N. Bonnia, I. Zainol et al., "Polyester-Kenaf composites: effects of alkali fiber treatment and toughening of matrix using liquid natural rubber," Journal of Composite Materials, vol. 45, no. 2, pp. 203-217, 2011. 